\title{
Extraterritorial non-refoulement: intersections between human rights and refugee law
}

\section{David James Cantor}

How does international law require States acting outside their own territories to treat refugees and other persons fleeing harm in their countries? ${ }^{2}$ This question has assumed increasing contemporary relevance in light of heightened externalised border controls, such as attempts by States to interdict migrant boats on the high seas in the Mediterranean (see, for instance Moreno-Lax 2012). However, the issue also arises in other contemporary scenarios, such as where persons seek protection in diplomatic or consular premises, where one State militarily occupies the territory of another, and where a State sets up a system for the extraterritorial processing of asylum claims.

This short analysis addresses the non-refoulement aspect of this extraterritoriality problem, i.e. protection against enforced removal to a territory where the person fears harm by a State acting outside its own territory. Inspired by the human rights focus of the volume overall, the chapter draws on current research by the author in order to examine this ever-topical concern against recent advances in the field of international human rights law. It not only confirms the view that the non-refoulement rule in human rights law applies extraterritorially, but also concludes that the resulting procedural implications should be taken seriously both for human rights law and for refugee law.

\section{Development of human rights doctrine on 'extraterritoriality'}

The many human rights treaties adopted by the United Nations (UN) and regional organisations offer a patchwork of different legal provisions for the protection of human rights by contracting States. Rather than reprise the basic elements of this framework, as the basis for subsequent discussion, the present

1 This intriguing question was recently raised by Ralph Wilde in his seminar on 'The Extraterritorial Application of the Non-refoulement Obligation in International Human Rights Law', 5th International Refugee Law Seminar Series, Refugee Law Initiative, School of Advanced Study, University of London. 5 May 2015. 
section instead outlines two doctrinal advances concerning extraterritoriality in human rights law: the jurisdiction of States acting extraterritorially (Wilde 2003); and the prohibition of refoulement to human rights violations in another territory.

\section{Extraterritorial jurisdiction of States}

International treaties governing human rights usually require that a contracting State respect and ensure these rights for persons subject to their territorial jurisdiction, i.e. who are present on its territory. However, students on the MA in Human Rights who have taken the law module in recent years will (or should!) be familiar with the idea that these same States will also sometimes be required to respect and/or ensure the human rights of individuals outside their territory. Indeed, it seems that human rights obligations arise where a State exercises certain forms of authority - or 'jurisdiction' - outside its own territory. This could be on the territory of another State or outside territory claimed by any State (e.g. on the high seas).

The famous judgment of the European Court of Human Rights in $\mathrm{Al}$ Skeini and Others $v$. UK identifies some scenarios in which such 'extraterritorial' jurisdiction exists. Firstly, where a State exercises effective control over a zone outside its national territory, whether as a consequence of lawful or unlawful military action, then it is apparently required to guarantee the full gamut of treaty rights to persons in that zone. ${ }^{2}$ Secondly, where State officials exercise control and authority over an individual - whether through diplomaticl consular acts or through the use of force - then this form of jurisdiction requires that the State guarantee the rights pertinent to the situation of that individual. 'In this sense, therefore, the Convention rights can be "divided and tailored". 3

This rationale is largely in line with the emerging doctrine being developed by other international courts and treaty body mechanisms. It strongly suggests that human rights obligations - or at least in relation to certain rights - will remain applicable to States in certain scenarios where certain concrete acts by their agents take place, or produce effects, extraterritorially.

\section{Refoulement to extraterritorial human rights violations}

The other main area in which international human rights law has developed doctrinally in order to address issues of extraterritoriality is in relation to the principle of 'non-refoulement'. Deriving originally from refugee law, this principle prohibits a State from removing an alien (foreigner) from its territory where this would result in serious harm to the alien outside that territory. However, since the 1980s, this principle has been developed considerably by international human rights law.

2 Al-Skeini and Others v. UK, paras 133-7.

3 Ibid., paras 138-40. 
In human rights law, the non-refoulement principle is derived principally from the core prohibition on torture, inhuman or degrading treatment or punishment. The idea is that if it is illegal for a State to torture a person under its own jurisdiction, then equally it must be prohibited to remove him/her to another territory where s/ he would be tortured. The principle finds concrete expression, inter alia, in Article 3 of the 1984 UN Convention Against Torture and it has been read into most other treaties that prohibit torture etc. in more general terms. ${ }^{4}$

The human rights non-refoulement principle has a strong speculative aspect, i.e. it is engaged by the envisaged risk extraterritorially. As such, it does not establish the removing State's responsibility for acts committed by others outside its territory. Rather, where the risk of serious abuse awaits the alien at the other end, the principle typifies the act of removal - initiated on the territory of the removing State - as 'degrading' or 'inhumane. ${ }^{5}$ For this reason, even where the abuse overseas does not take the specific form of torture but rather interference with other rights (e.g. fair trial), the non-refoulement principle can prevent removal where the abuse of other rights is 'flagrant'. ${ }^{6}$

\section{Non-refoulement in extraterritorial contexts}

Human rights law frames extraterritorial considerations according to two distinct rationales, as shown above. In the context of refoulement, the removing State's responsibility is engaged by its own actions on its territory albeit in light of the potential eventual consequences extraterritorially. Where a State acts outside its territory, human rights obligations bite directly wherever jurisdiction is exercised. What, though, is the legal position where both rationales apply simultaneously, i.e. where a State acting extraterritorially is faced with a situation of potential refoulement?

\section{Applicability of non-refoulement principle extraterritorially?}

The doctrinal analysis above shows that States acting extraterritorially will sometimes be exercising jurisdiction in a manner constitutive of human rights obligations. The question here is whether those obligations encompass the nonrefoulement principle.

4 Thus, the European Court of Human Rights reads the principle into Article 3 of the 1950 European Convention on Human Rights in Soering v. UK; the InterAmerican Court of Human Rights reads it into Article 5 of the 1969 American Convention on Human Rights in its Advisory Opinion OC-21/14 on Rights and Guarantees of Children in the Context of Migration andlor in Need of International Protection; and the Human Rights Committee reads it into Article 7 of the 1966 International Covenant on Civil and Political Rights in Chitat Ng v. Canada.

5 See the European Court of Human Rights in Soering v. UK, para. 91.

6 See the European Court of Human Rights in Othman (Abu Qatada) v. UK, paras. 258-85. 
In principle, in the first Al-Skeini scenario of a State exerting effective control over a zone of another State's territory, non-refoulement should remain applicable alongside other human rights guarantees. Thus, in the example of military occupation, human rights law presumably should prevent an occupying State from removing a person from occupied territory where the risk of human rights abuse at the other end exists. ${ }^{7}$

Less straightforward is the second Al-Skeini scenario of the State agent(s) exerting control and authority over an individual extraterritorially. In contrast to the first scenario, the State agent(s) is/are acting in a context where the wider apparatus of their own State is not present and in control. We are thus much less likely to be talking about situations involving the 'removal of aliens' in relation to which much of the human rights non-refoulement doctrine has been developed. A broader spectrum of scenarios exists in which the principle of non-refoulement is, in the words of the Al-Skeini judgment, more or less relevant to the situation of that individual.

Some of these scenarios will have clear and direct parallels with the established non-refoulement removal paradigm. This is the case, for instance, where a State official attempts to transfer an individual under his/her power to another country (whether by kidnap or formal procedure) where the risk of harm exists. A similar scenario may be where a State official on a boat turns back, or escorts back, a boat full of migrants encountered on the open sea to a territory where they face harm. In these scenarios, the direct relationship between the act of the State agent and exposure to envisaged harm in another territory should bring the non-refoulement principle into play. ${ }^{8}$

However, in other scenarios, it may be less easy to establish a sufficiently proximate link between the extraterritorial official act and the envisaged harm necessary to engage the non-refoulement principle. If so, then we may see greater jurisprudential development around the legal threshold for such proximity in the future. The challenge will be particularly acute in cases that do not involve use of force against a person by a State agent but rather revolve around diplomatic or consular acts. It will be interesting to see the extent to which such developments redraw the international law parameters of diplomatic asylum, i.e. temporary asylum granted on diplomatic premises (Noll 2005).

7 Even if the laws of war apply simultaneously as lex specialis, and thus modify certain human rights obligations, the two bodies of law largely march in line in prohibiting refoulement. For a more detailed analysis of the position under the laws of war, see Cantor (2014).

8 This has been confirmed by the European Court of Human Rights in cases such as, respectively, Öcalan v. Turkey and Hirsi Jamaa and Others v. Italy. 


\section{Procedural implications of the applicability of the non-refoulement principle?}

One element that is missing from much of the discussion surrounding these themes is the question of whether, or to what extent, procedural guarantees apply in this extraterritorial context. In other words, does human rights law require that certain procedural or due process guarantees must be observed by State agents acting outside their territory when deciding whether the principle of non-refoulement applies to a particular situation or individual? From an administrative perspective, this processual aspect is crucial since it is not usually apparent from a quick glance whether or not any individual should benefit from the non-refoulement rule, but rather requires deeper investigation of their particular circumstances.

Where potential refoulement arises in the removal context on a State's own territory, international human rights jurisprudence has increasingly adopted the consensus that the removal decision must be taken in line with due process guarantees (Cantor 2015). The various international human rights systems provide different legal bases and rationales for this development. Nonetheless, where the risk of refoulement is in issue, all generally require, inter alia, that the alien: has access to decision-making by a 'competent' national authority; independent, individual, rigorous and prompt scrutiny of the issue; automatic suspensive effect of the removal measure; a reasoned decision; and often the opportunity to challenge it at a higher instance, usually the national courts.

There is little doubt that these guarantees would apply in the first Al-Skeini scenario, where the State effectively continues to act as a State albeit on another State's territory. However, the implications are likely to be much more farreaching in the second Al-Skeini scenario where the agent(s) of the State acting outside its territory exercise control and authority over an individual. Indeed, they would need either to be, or to have recourse to, authorities competent to evaluate these cases and take such decisions. Moreover, the requirement to do so in accordance with due process standards entails in itself access to a considerable bureaucratic (and also likely judicial) infrastructure.

For instance, where boats of migrants are intercepted and pushed back on the high seas, do these human rights guarantees require a proper decisionmaking process for any passengers who express or reasonably may be believed to have a fear of harm? In other words, does the full gamut of procedural guarantees applicable to refoulement in the context of removal apply? Recent case-law from the European Court of Human Rights suggests this question is to be answered in the affirmative, holding that the migrants' right to an effective remedy was breached by the fact that they had 'no access to a procedure to identify them and to assess their personal circumstances' before they were directed back to a territory where they faced possible harm. ${ }^{9}$

9 See Hirsi Jamaa and Others v. Italy, esp. paras. 196-207. 
If correct, then in scenarios where the extraterritorial act of a State agent gives rise to an envisaged future risk of harm sufficient to engage the nonrefoulement rule, it would appear that relatively extensive procedural obligations materialise requiring that the risk to be assessed and determined in accordance with due process standards. In the migrant boat example, this would suggest that access to such facilities must be provided, whether on the intercepting boat or by disembarkation at a territory where such procedures are available. From the human rights perspective, the exercise of State authority over a person brings with it certain inescapable human rights obligations.

\section{Conclusions: intersections between human rights and refugee law}

This brief analysis of extraterritoriality shows that State obligations under international human rights law do not stop at its borders nor are they blind to events beyond them. Rather, the jurisprudence requires a State to take account of the human rights implications of expelling or removing an alien across such borders and to comply with human rights obligations when it exercises jurisdiction beyond those borders. Both requirements are concerned with extraterritoriality but from different standpoints and thus they apply different rationales.

Whereas refugee law pioneered the development of the non-refoulement principle, it is largely silent on whether this principle and other refugee law obligations apply when States act beyond their own borders. Indeed, this ambivalence is amply demonstrated in one of the few such cases to be decided on a refugee law basis before the courts: in a 1993 decision in Sale, the United States (US) Supreme Court held by a majority that refugee law treaty obligations did not apply when the US interdicted boats from Haiti on the high seas. Although the decision is much criticised, still it stands against the lack of any international tribunal for refugee law where its rationale might be challenged.

By contrast, recent jurisprudential developments in international human rights law strongly suggest that a State acting outside its own territory remains bound by the human rights version of the non-refoulement principle. However, of perhaps greater significance than the mere applicability of this principle of extraterritoriality are the far-reaching procedural implications that this entails, particularly in light of the recent jurisprudential advances in the human rights field confirming the existence of robust due process standards in cases where non-refoulement may be in issue. In brief, it would seem that the provision of access to proper procedures for making such determination is obligatory.

These findings are significant not only in their own right but also for how they bolster refugee law. Thus, in some human rights systems, the relevant procedural standards also require that refugee status be determined in accordance with the same due process guarantees. In other words, at least for 
people outside their country and in the hands of a State acting extraterritorially, the duty to determine human rights refoulement risk marches hand-in-hand with a requirement to determine refugee status. Alternatively, access to protection against refoulement on human rights grounds can serve as a backstop to refugee status, given the degree of overlap between the two.

\section{Bibliography}

\section{Instruments}

American Convention on Human Rights, 1969

Convention Against Torture, 1984

European Convention on Human Rights, 1950

International Covenant on Civil and Political Rights, 1966

\section{Cases}

European Court of Human Rights, 1989, Soering v. UK

European Court of Human Rights, 2012, Othman (Abu Qatada) v. UK

European Court of Human Rights, 2014, Öcalan v. Turkey

European Court of Human Rights, 2011, Al-Skeini and Others v. UK

European Court of Human Rights, 2012, Hirsi Jamaa and Others v. Italy

Human Rights Committee, 1994, Chitat Ng v. Canada

Inter-American Court of Human Rights, 2014, Advisory Opinion OC-21/14 on Rights and Guarantees of Children in the Context of Migration andlor in Need of International Protection

\section{Commentaries}

Cantor, D. J. (2014) 'Laws of unintended consequence? nationality, allegiance and the removal of refugees during wartime', in D. J. Cantor and J. F. Durieux (eds.), Refuge from Inhumanity? War Refugees and International Humanitarian Law (Leiden: Martinus Nijhoff), chapter 14.

- (2015) 'Reframing relationships: revisiting the procedural standards for refugee status determination in light of recent human rights treaty body jurisprudence', Refugee Survey Quarterly 34 (1), pp. 79-106.

Moreno-Lax, V. (2012) 'Hirsi v. Italy or the Strasbourg court versus extraterritorial migration control?', Human Rights Law Review 12 (3), pp. 574-98.

Noll, G.,(2005) 'Seeking asylum at embassies: a right to entry under international law?', International Journal of Refugee Law 17 (3), pp. 542-73. 
Wilde, R. (2013) 'The extraterritorial application of international human rights law on civil and political rights', in N. Rodley and S. Sheeran (eds.), Routledge Handbook on Human Rights (London: Routledge), chapter 35. 